\title{
Research Articiz: Effect of planting methods on yield attributes and yield of pre released rice culture RDR 1140
}

\author{
GIRDOZ SHAHANA, N. SANHYA KISHORE, B. JOSEPH AND G. PRAVEEN
}

Article Chronicle:

Received :

15.07.2017;

Accepted :

30.07.2017

KEY WoRDS :

Varieties, Methods of planting, Grain yield
SUMMARY : A field experiment was conducted to evaluate new rice culture RDR 1140 for different methods of establishments during Kharif 2016 - 17 at Regional Sugarcane and Rice Research station, Rudrur, Nizamabad (district). It was laid out in split plot design viz., new rice culture RDR 1140 and popular existing variety MTU 1010 as main plots and three planting methods - Broadcasting sprouted seed on puddled seedbed, Drum seeder planting (Wet) and Normal transplanting. No significant difference in grain yield was noticed for two varieties but planting methods significantly influenced grain yield. Normal transplanting method and Direct sowing with Drum seeder method recorded at par grain yield of $8426 \mathrm{~kg} \mathrm{ha}^{-1}$ and $8195 \mathrm{~kg} \mathrm{ha}^{-1}$, respectively and it was significantly higher over Broad casting method with grain yield of $5120 \mathrm{~kg} \mathrm{ha}^{-1}$. Among two rice varieties RDR 1140 recorded yield advantage of 5.8\% with two days early maturity in Drum seeder and 19\% yield increase with three day early maturity in Normal method over existing popular variety MTU 1010.Hence RDR 110 can be recommended over existing variety MTU 1010 either through Normal transplanting method or Direct seeding with Drumseeder depending upon available resources with farmer.

How to cite this article : Shahana, Firdoz, Kishore, N. Sanhya, Joseph, B. and Praveen, G. (2017). Effect of planting methods on yield attributes and yield of pre released rice culture RDR 1140. Agric. Update, 12(TECHSEAR-5) : 1436-1439; DOI: 10.15740/HAS/AU/12.TECHSEAR(5)2017/1436-1439.

\section{Author for correspondence :}

\section{FIRDOZ SHAHANA}

Regional Sugarcane and Rice Research Station, Rudrur, NIZAMABAD (TELANGANA) INDIA

See end of the article for authors' affiliations 